\title{
COMPARISON OF EMERGENCY SITUATIONS DURING SHIPS' NAVIGATION UNDER EXTREME CONDITIONS
}

\section{ПОРІВНЯННЯ АВАРІЙНИХ СИТУАЦІЙ ПРИ ПЛАВАННІ СУДЕН В ЕКСТРЕМАЛЬНИХ УМОВАХ}

\author{
I. Surinov, PhD student \\ І. Л. Сурінов, аспірант \\ National university “Odessa maritime academy”, Ukraine \\ Національний університет «Одеська морська академія», Україна
}

\begin{abstract}
Sea-going vessels spend about $80 \%$ of their sailing time at the open sea and about $20 \%$ under extreme conditions in confined waters. However, the number of accidents under extreme conditions is more than $90 \%$ of their total. As a result of sea disasters, about 200 thousand people die annually in the world, of which 50 thousand - directly in the water after a shipwreck, and 50 thousand die on life-saving appliances in conditions that are not really extreme. The main factors of accidents at sea, which can develop into emergencies, are violations of safety of navigation. Statistics show that most often these violations lead to navigation accidents. In total, ship collisions, bulkheads and groundings account for at least $80 \%$ of the accidents. The main reason for these situations is "human factor ", which has not been sufficiently studied and is constantly developing. Firstly, it concerns the adequate actions of operators of complex systems being in inadequate (emergency and emergency) operation of the vehicle. In this sense, to become relevant, the research must harmonize the interaction between phenomena, processes, mechanisms and systems controlled by ship operators. Special attention is paid to increasing the safety of operation of ships using the methods of event management during pre-pilot training of ship crews in crewing companies.

The analysis of emergency situations during ships' navigation under extreme conditions plays a significant role while studying crew behavior in such situations. Based on the statistical data, a special checklist was developed that will help prepare crew members for actions in emergency situations. Also, this checklist will provide an opportunity to reduce the risk of a pre-emergency situation.
\end{abstract}

Keywords: emergency situations, checklist, extreme conditions, crew actions, navigation training.

\section{PЕФЕРАТ}

Морські судна близько 80\% ходового часу проводять у відкритому морі і близько 20\% в екстремальних умовах обмежених вод. Однак кількість аварійних подій в екстремальних умовах складає більше 90\% від загальної їх кількості. В результаті морських катастроф щзорічно в світі гине близько 200 тис. людей., з них 50 тис. - безпосередньо у воді після аваріі судна, а 50 тис. гине на рятувальних засобах в умовах, які не є насправді надзвичайними. Основним фактором аварій на морі, які здатні перерости в надзвичайні ситуації, є порушення в галузі безпеки мореплавства. Статистичні дані показують, щзо найчастіше ці порушення призводять до навігаџійних аварій. У сукупності зіткнення суден, навали і посадки на мілину становлять не менше 80\% від усієї кількості аварій. Основною причиною таких ситуацій $\epsilon$ «людський фактор », який недостатньо досліджений $і$ знаходиться на стадії розвитку. Поперше, ие стосується адекватних дій операторів складних систем під час знаходження в неадекватних (надзвичайних і аварійних) умовах експлуатації транспортного засобу. У иьому 
сенсі актуальними стають дослідження по гармонізаиії взаємодї̈ між явищами, процесами, механізмами і системами, якими керують суднові оператори. Особливе увага приділяється підвищенню безпеки експлуатаиії суден методами управління подіями під час підготовки екіпажів суден в крюёнгових компаніях.

Аналіз аварійних ситуащій при управлінні суднами в екстремальних умовах має вагому роль в дослідженні поведінки екіпажу у таких ситуаціях. На підставі отриманих статистичних даних був розроблений спеціальний чек лист, який допоможе підготувати членів екіпажу до дій в аварійних ситуачіях. Також даний чек лист надає можливість знизити ризик виникнення передаварійної ситуації.

Ключові слова: аварійні ситуації, чек-лист, екстремальні умови, дії екіпажу, навігаційна підготовка.

\section{Defining the general matter and its connection to important scientific or practical objectives}

The safety of the process of controlling the movement of the vessel is determined by the intellectual actions of the human operator $(\mathrm{HO})$, who uses the available resources to influence the course of maneuvering. Such resources are the skills in planning the system operation algorithm adequate to extreme sailing conditions and its ability to timely adjust the control process in the event of an emergency. The qualitative criteria that characterize his actions are sensory, logical, or "motor" mistakes made during control.

The safety of maneuvering under external influences, for which this vessel is designed, and other disturbances with the proper functioning of the ship's technical means that carry out its movement and control, is ensured by the presence of a stable skill in the HO, which controls itself or directs the bridge team.

Under extreme operating conditions of a $\mathrm{HO}$, the number and composition of elementary operations increases, and it acts at the level of a stable skill, and in emergency situations it is necessary to use calculations and mental operations to make a decision, which leads to a slowdown in the control process.

For this reason, the systems and devices for navigational support of the control process should be designed so that information is processed by automatic devices and provided to the operator in the form of knowledge that is sufficient for a quick decision making in an adequate situation. In addition, the formation of a special skill is required for the emergency department, which manages the process of controlling the ship or the bridge team, in order to make a timely decision adequate to the developing situation.

\section{The analysis of previous researches and definition of new trends in problem solution}

In the research [11], the analysis of the behavior and actions of the captains who manage the operation of ships is carried out. It is noted that even the most conscientious and responsible captains are not able to follow all the rules and regulations for safe work. This is due to the lack of sufficient coordination of the three constituent parts of the process - external constraints, motion factors and psychophysiological characteristics of the human operator (HO), as an element of the system.

The dissertation [12] describes the chronology of accidents on ships of water transport in Ukraine for 2015 - 2020. In total, 338 emergency cases were considered, while, in addition to statistical data, the chronology of events and the reasons for their occurrence are given. The main drawback of this work is the lack of documentary evidence of the actions of the captain and crew members, and conclusions about the causes of the accident are made on the basis of insufficient information.

The substantiation of the methods and means for the implementation of accident-free navigation was presented in [13]. However, the analysis of the causes of accidents has not been carried out sufficiently. For this reason, the considered devices and the proposed methods are not adequate, and the means used are insufficient to ensure guaranteed navigation safety. 
A new direction for ensuring trouble-free maneuvering is the creation of local port highprecision navigation control and communication systems [14]. Such systems allow quickly determine the parameters of the position and movement of the vessel under extreme conditions of port waters. However, they are not a decision support system and require additional time to process information and make a decision.

In [15], methods of organizing mooring operations at the roadsteads of large-tonnage tankers in the Feodosiya Gulf are presented. However, the planning of the trajectory and the issues of using tugs for maneuvering have not been considered.

The collection of normative documents [16] contains requirements on training a sea pilot and an operator's pilot, as well as qualification requirements for their competence in the regulatory documents of the International Maritime Organization (IMO). However, the issues of documenting the actions of the pilot when navigating the vessel, organizing the interaction of the pilot and the captain and responsibility in case of accidents have not been resolved.

In [17] it is noted that the average age of inland and mixed navigation vessels is increasing. A high indicator of the "age" component of ships refers to objective characteristics and determines a high level of accidents. In addition to technical reasons, the analysis of incidents shows that the crews are not prepared to work in emergency situations when the ship's controls and devices that provide movement fail.

In works $[18,19]$ it is noted that in the exclusive economic zone of Ukraine the facilities of waterways don't meet the requirements for the organization of accident-free navigation. The number of control correcting stations of satellite systems is not enough to determine the position of the vessel using high-precision methods and to ensure the normal operation of automated identification systems (AIS). To reduce accidents, it is proposed to create regional navigation safety systems and improve the training level of bridge operators and specialists of coastal navigation systems.

In [20], the analysis of accidents with ships of limited navigation areas that occurred from 2017 to May 2021 was carried out. In total, 441 accidents and incidents with the SORP were considered. There is a steady increase in accidents for ships over 10 years old, with a peak of accidents for ships with an age of 25-30 years. Most of the accidents occur with ships over 20 years old. In total, 91 vessels were lost. Among the main causes of death are violations of the technology for the transportation of goods, unskilled work of the bridge team and the failure of ship devices that provide movement and control.

In [21], it is noted that the application of directive rules and instructions for the use of traffic control systems makes it possible to identify a number of potential hazards together with the level of risk of their impact. It is argued that a reduction in the number of accidents can be achieved by improving policy rules and regulations. To unify the recommendations under the auspices of the IMO, model courses have been developed that determine the requirements and scope of training for ship specialists necessary to ensure the safe operation of the ship.

In work [22], the development of theoretical prerequisites for the organization of accident-free navigation is carried out, which provides a solution to the scientific and practical problem of guaranteed safe control of the ship during maneuvering. A hypothesis is put forward about the possibility of ensuring safe maneuvering by increasing the accuracy of trajectory planning, purposefulness in making decision on control and using algorithms for operator activity to increase its performance.

The obtained scientific results are a solution to the scientific problem of creating the theoretical foundations of navigation and the development of adaptive systems for safe maneuvering control. However, the issues of preparing the bridge team for work under extreme conditions in emergency situations were not considered in the work.

In work [23] it is noted that the equipment of the vessel with information, informationcomputing and expert systems requires a comprehensive and specialized training of maritime specialists.

In such systems, $\mathrm{HO}$ is the most unpredictable link. His behavior under extreme conditions in emergency situations depends on the psychophysical characteristics. Therefore, it is necessary to 
minimize the consequences of an incorrect decision made by the bridge crew on the general state of safe operation of the vessel. However, methods of ensuring the preparation of the bridge team for work in such conditions have not been considered.

In works $[24,25]$ it is emphasized that in the practice of ships' operation there are cases when the captain entrusts the control of the vessel to the pilot. If accidents occur, the captain is accused of non- supervising his work. Meanwhile, the process of movement and control is fleeting and often there is not enough time to discuss the decisions made, which forces the captain to prepare for sailing under cramped conditions very carefully. A technique for assessing the consistency of motion factors and operator characteristics is proposed.

\section{The research objective}

A detailed analysis of the causes of accidents shows that they occur due to the actions of individuals, in which organizational errors of a group of operators prevail in the preparation of the maneuvering control process and its implementation. At the same time, a gap is noted between the complexity of modern technology and the psychological capabilities of a human operator as an element of 'a human-machine' system. For this reason, the study of the causes of accidents under extreme conditions is relevant. Based on the data received, it is possible to compile a checklist of actions to prevent the occurrence of pre-emergency situations.

\section{Presenting the main material of the research with a full grounding of received scientific results}

Navigational accidents occur relatively frequently in winter, but there is insufficient systematic knowledge of the circumstances under which they occur. The article [1] presents an analysis of shipping accidents in the northern part of the Baltic Sea that occurred in the period 20016-2020. The analysis is based on the integration of various data sources with the goal of disaster recovery based on the best available data sources. In addition to basic information about accidents from the original accident databases, data from the automatic identification system is used to obtain information about the type of operation during which the accident occurred, as well as in other dynamic aspects of the accident scenario. Finally, atmospheric and sea ice data are used to reconstruct the navigation conditions in which accidents occurred. The purpose of the analysis is to provide quality information about patterns and exceptional cases at random. Accordingly, visual data analysis has been chosen as an analysis approach because of its usefulness for obtaining quality knowledge from data sources through the combination of visual techniques and human-data interaction. Particular attention is paid to the evidence of the identified accident patterns. The results are primarily useful for improving risk analysis with a focus on the risks of oil spills in winter and for developing realistic training scenarios for oil spill response operations. However, this article does not consider the possible correlation of the influence of meteorological factors with other northern regions.

Various national maritime authorities and international organizations are interested in the implementation of risk management processes in decision-making to prevent accidents in waterway navigation. There is an ongoing need for approaches, models and tools for identifying, analyzing and assessing the risks of shipping accidents, as well as strategies for their preventive management in an organizational setting. [2] provides a comprehensive overview of academic work in this area of research with the aim of identifying patterns, trends and gaps that guide future research and development, with a particular focus on the Baltic Sea region. To understand the links between research in the Baltic Sea Region and the global community, bibliometric analysis is carried out with an emphasis on identifying dominant factors and social networks in the research community. Based on the results, the patterns of the historical evolution of the field of study are revealed and information about current trends is obtained, which is used to determine future directions of research. The tendencies obtained do not solve this problem. For this reason, it is necessary to further study their implementation.

With the increase in the frequency of shipping, the safety of shipping has become a major concern, especially in view of economic losses, human casualties and environmental hazards. As a 
contributing factor, the state of the sea plays an important role in the safety of navigation. However, the types of marine hazardous conditions that cause serious shipping accidents are not well understood. To solve this problem, the work [3] analyzed the characteristics of the state of the sea during accidents of ships that occurred in bad weather or strong sea waves, based on accidents within 10 years. The sea state parameters of the numerical wave model, i.e. significant wave height, mean wave period and mean wave direction, were analyzed for selected ship accidents. The results showed that difficult sea conditions with the simultaneous occurrence of wind and waves pose a threat to sailing vessels, especially when these conditions include the same wave periods and oblique wave directions.

Marine accidents that occur often have serious impacts on the environment, society and economy. Many accidents happened in the last century. Studies [4 - 10] note that the traditional approach to maritime safety is generally reactive. This indicates that accidents are unpredictable, and this is the most fundamental problem in safety science. In this regard, a review of some of the known accident theories / models was carried out comparing their different attributes. The literature review suggests that over the years, accident theories / models have been created in different disciplines, and they have evolved along with changes in society. Research shows that marine accidents occur in a complex socio-technical context. In such accidents, a single root cause can be traced in a chain of causation, but this is not sufficient to prevent similar accidents in the future. For this reason, the analysis of emergency situations under extreme conditions is most relevant.

Determination of the causes of an accident and the development of measures to prevent the future can be performed in two ways: statistical analysis of the generalized causes of the accident; detailed analysis of the chronology of the incident, the algorithm of the boatmaster's actions when managing the maneuvering process. Statistical analysis does not allow us establish a specific cause of the accident, but only allows us speak about the type of incident.

A detailed analysis of the incident includes checking the meaningful model of the control system, the composition of its elements, as well as the analysis of direct, reverse and local connections, in the presence of a given system operation algorithm (Fig. 1).

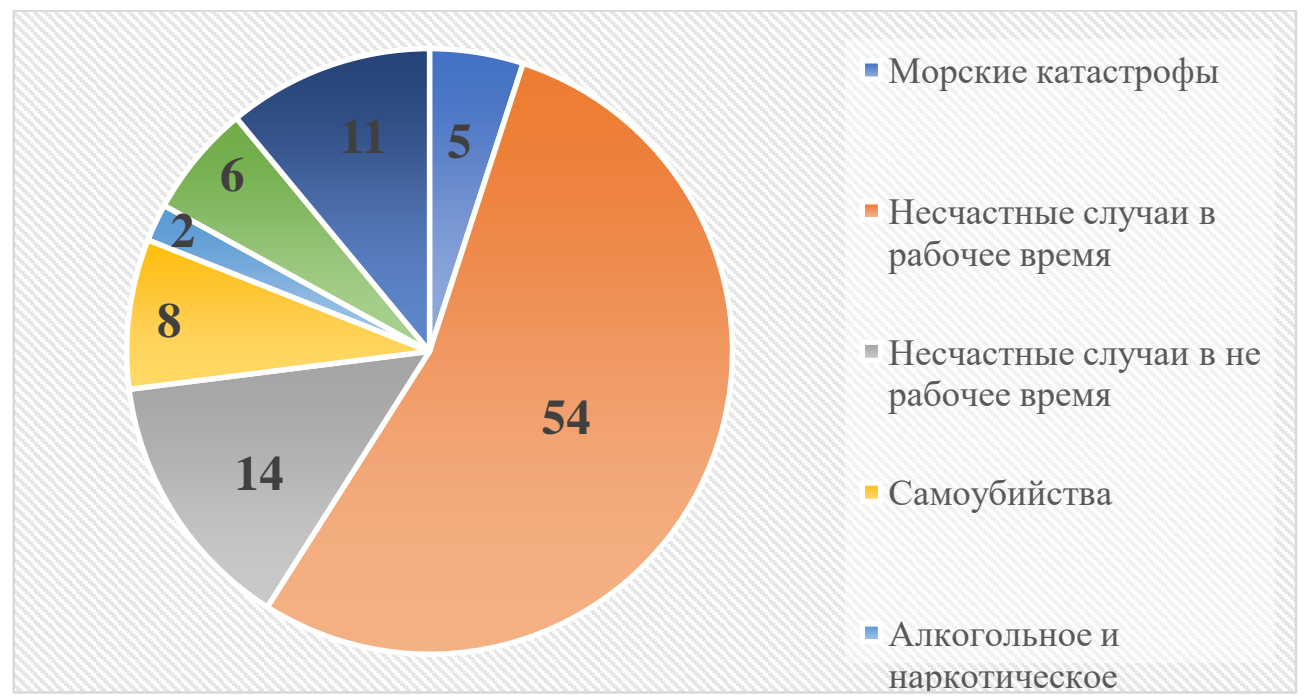

Fig. 1. Analysis of incidents at sea for 2016 - 2020

In the process of algorithmization of the boatmaster's activity on the basis of the criterion of consistency of his psychophysiological characteristics and navigation factors, three options for operational management are identified - the preparation of navigation processes, the process of their implementation and sea operations at their completion. However, the issues of organizing the bridge team and the distribution of functional responsibilities in managing the maneuvering process have not been fully described.

For high-quality preparation of the bridge team for work under extreme conditions, in case of emergency, it is proposed to use a checklist, the form of which is given in Table 1. 
Table 1. Checklist of preparation for work of the bridge team in case of failure of the main engine

\begin{tabular}{|c|c|c|c|c|}
\hline No & Actions & Unit & Data & Remarks \\
\hline 1 & $\begin{array}{l}\text { Current data at the time of maneuvering: } \\
\text { a) Deadweight } D \\
\text { б) Middle draft } \mathrm{D}_{m} \\
\text { в) Maximum breadth } B\end{array}$ & $\begin{array}{l}\mathrm{t} \\
\mathrm{m} \\
\mathrm{m}\end{array}$ & $\begin{array}{l}\ldots \\
\cdots \cdots \\
\cdots \cdots \\
\cdots\end{array}$ & $\begin{array}{l}\text { Ship's } \\
\text { particulars }\end{array}$ \\
\hline 2 & Hydrodynamic drag coefficient $K$ & $\mathrm{~kg} / \mathrm{m}$ & $\begin{array}{l}\ldots \ldots \\
\ldots .\end{array}$ & \\
\hline 3 & Maximum speed at port according to the requirements $V_{p}$ & y3 & $\begin{array}{l}\ldots \ldots \\
\ldots\end{array}$ & $\begin{array}{l}\text { Port } \\
\text { regulations }\end{array}$ \\
\hline 4 & Maximum screw stop force Рмах & $\mathrm{H}$ & $\ldots \ldots$ & \\
\hline 5 & Axle thrust force of tugs $X P_{\sigma x}$ & $\mathrm{H}$ & $\begin{array}{l}\ldots \ldots \\
\ldots . \\
\ldots\end{array}$ & $\begin{array}{l}\text { Ship's } \\
\text { particulars }\end{array}$ \\
\hline 6 & Permissible speed for towing $V_{\max }$ & knt & $\begin{array}{l}\ldots \ldots \\
\ldots\end{array}$ & \\
\hline 7 & Braking distance from $V_{p}$ till full stop $S_{b r}$ & $\mathrm{cbt}$ & $\begin{array}{l}\ldots \ldots \\
\ldots\end{array}$ & \\
\hline 8 & Advance $l_{l}$ at turning angle $15^{0}$ & $\mathrm{cbt}$ & $\ldots \ldots$ & \\
\hline 9 & Navigational stock $S_{\mathrm{H}}$ & $\mathrm{cbt}$ & $\ldots \ldots$ & $0.1 \mathrm{cbt}$ \\
\hline
\end{tabular}

Its use can significantly reduce the time for assessing the situation and making a decision in case of emergency.

\section{Conclusions and further research prospects}

The analysis of the reviewed literature shows that the technology of command control of the ship under extreme conditions in emergency situations for the organization of safe maneuvering has not been thoroughly developed .

Further improvement of the control system for the maneuvering process must be carried out in several directions: special training of the bridge team to control the ship in case of emergency; timely assessment of the risk of an emergency and proper preparation of adequate measures to prevent it; development of algorithms for the actions of the bridge team in emergency situations; development of devices for assessing the moment of onset of emergency situations and decision support systems for maneuvering; to develop meaningful models for identifying errors that may arise when performing an eye, instrument or radar decision-making plan adequate to extreme conditions.

\section{REFERENCES}

1. An analysis of wintertime navigational accidents in the Northern Baltic Sea / FlorisGoerlandt, Habtamnesh Goite, Osiris A. Valdez Banda и др.]. // Safety Science. - 2017. - №92. - С. 6684. https://doi.org/10.1016/j.ssci.2016.09.011

2. Ketki Kulkarni. Preventing shipping accidents: Past, present, and future of waterway risk management with Baltic Sea focus / Ketki Kulkarni, Floris Goerlandt, Jie Li. // Safety Science. - 2020. - №129. - C. 104-115. https://doi.org/10.1016/j.ssci.2020.104798

3. Zhiwei Zhang. Global ship accidents and ocean swell-related sea states / Zhiwei Zhang, XiaoMing Li. // Natural hazards and Earth system sciences. - 2017. - №17. - C. 2041-2051. https://doi.org/10.5194/nhess-17-2041-2017

4. Zobair Ibn Awal. A Study on Accident Theories and Application to Maritime Accidents / Zobair Ibn Awal, Kazuhiko Hasegawa. // Procedia Engineering. - 2017. - №194. - C. 298-306. https://doi.org/10.1016/j.proeng.2017.08.149 
5. Fatal accidents and injuries among merchant seafarers worldwide / SE Roberts, D. Nielsen, A. Kotłowski, B. Jaremin. // Occupational Medicine. - 2014. - №64. - C. 259-266. https://doi.org/10.1093/occmed/kqu017

6. Z.I. Awal, Development of logic programming technique for marine accident analysis, Doctoral dissertation, Graduate School of Engineering, Osaka University, Japan, 2016. https://doi.org/10.18910/59594

7. Keefe, P., Disasters at sea and their impact on shipping regulation. In Marine Link. Available at: http://www.marinelink.com/news/disasters-shippingimpact371542.aspx. [Accessed: 12 June 2021].

8. J.U. Schrder-Hinrichs, E. Hollnagel, and M. Baldauf, From Titanic to Costa Concordia-a century of lessons not learned. WMU Journal of Maritime Affairs, Vol. 11 (2012), No. 2, pp. 151-167. https://doi.org/10.1007/s13437-012-0032-3

9. M. Afenyo, F. Khan, B. Veitch, M. Yang Arctic shipping accident scenario analysis using Bayesian Network approach Ocean Eng., 133 (2017), pp. 224-230. https://doi.org/10.1016/j.oceaneng.2017.02.002

10. M. Luo, S.-H. Shin Half-century research developments in maritime accidents: future directions Accid. Anal. Prev., 123 (2019), pp. 448-460. https://doi.org/10.1016/j.aap.2016.04.010

11. An era of inland water transport accidents and casualties: the case of a low-income country / Mia, Md Jobayer, Uddin, Md Imran, Awal, Zobair Ibn, Abdullah, Ahammad. // Journal of International Maritime Safety, Environmental Affairs, and Shipping. - 2021. - №5. - C. 32-39. https://doi.org/10.1080/25725084.2021.1919432

12. Obertiur K. L. Povыshenye bezopasnosty эkspluatatsyy sudov metodamy upravlenyia sobыtyiamy: dys. kand. tekhn. nauk: 05.22.20 / Obertiur Konstantyn Leonydovych - Odessa, 2015. - $223 \mathrm{~s}$.

13. R. Flage, T. Aven, E. Zio, P. Baraldi Concerns, challenges, and directions of development for the issue of representing uncertainty in risk assessment Risk Anal., 34 (2014), pp. 1196-1207. doi.org/10.1111/risa.12247

14. F. Goerlandt, J. Montewka, W. Zhang, P. Kujala An analysis of ship escort and convoy operations in ice conditions Saf. Sci. (2016) https://doi.org/10.1016/j.ssci.2016.01.004

15. Hladkykh Y.Y. Razrabotka standarta эlektronnoho obmena ynformatsyei dlia sudov na vnutrennykh vodnыkh putiakh Ukraynы // Sudovozhdenye: Sb. nauchn. trudov / ONMA, Vыр. 11. - Odessa: «YzdatYnform», 2006

16. Tsыmbal N.N. Vыbor optymalnoho manëvra raskhozhdenyia pry nalychyy raspredelënnыkh navyhatsyonnыkh prepiatstvyi // Mezhdunarodnaia nauchno-tekhnycheskaia konferentsyia «Sovremennoe sudokhodstvo y morskoe obrazovanye» - Odessa, 7-9 aprelia 2004. - S.36-37.

17. Nekrasov V.A. Morekhodnost y tekhnycheskaia ustoichyvost sudna // Hydromekhanyka sudna, Trudы NKY. 1985. - S.61-72.

18. Kapustyn V.V. Otsenka resursnыkh pokazatelei sudovoi tekhnyky cherez pokazately nadezhnosty: materyal tekhnycheskoi ynformatsyy / V.V. Kapustyn, V.N. Lytoshenko // Vestnyk SevHTU. - Sevastopol: Yzd-vo SevHTU, 2002. - Vыр. 38: Mekhanyka, эnerhetyka, эkolohyia: Korablestroenye. - S. 75-77.

19. Ehorov H.V. Yssledovanye ryska pry эkspluatatsyy sudov smeshannoho plavanyia // Zb. nauk. prats UDMTU. - Mykolaiv: UDMTU, 2000. - № 5. - S. 49-59.

20. Ershov A. A. Teoretycheskye osnovы у metodы reshenyia pryorytetnыkh problem bezopasnosty moreplavanyia: avtoref. dys. d-ra tekhn. nauk: 05.22.19 / A. A. Ershov. , 2000. $44 \mathrm{~s}$. 
21. Menshykov V. Y. Metrolohycheskaia nadezhnost navyhatsyy s uchetom nepolnotы ynformatsyy: avtoref. dys. d-ra tekhn. nauk: 05.22.19 / V. Y: Menshykov., 1995. -40 s.

22. Emelianov M.D. Otsenka ryska y krytycheskye эlementы morskykh sudov //Problemы razvytyia morskoho flota: Sb. nauchn. trudov. - 2009. - S. 20-41.

23. F. Goerlandt, G. Reniers On the assessment of uncertainty in risk diagrams Saf. Sci., 84 (2016), pp. 67-77. https://doi.org/10.1016/j.ssci.2015.12.001

24. W. Zhang, F. Goerlandt, P. Kujala, Y. Wang An advanced method for detecting possible near miss ship collisions from AIS data Ocean Eng., 124 (2016), pp. 141-156. https://doi.org/10.1016/j.oceaneng.2016.07.059

25. J. Zhang, Â.P. Teixeira, C. Guedes Soares, X. Yan, K. Liu Maritime transportation risk assessment of Tianjin port with Bayesian Belief Networks Risk Anal., 36 (2016), pp. 11711187. https://doi.org/10.1111/risa.12519 